\title{
Abertura ao mistério de Deus e a revelação salvífica em W. Pannenberg. Em Jesus Cristo a história humana se eleva ao divino
}

\author{
Orientador: Mario de França Miranda \\ Doutorando: Romildo Henriques Pinas \\ Área de Concentração: Teologia Sistemático-Pastoral \\ Linha de Pesquisa: Fé e Cultura
}

O presente estudo procura refletir a problemática da relação ser humano e Deus no pensamento de Wolfhart Pannenberg. Para a elaboração do trabalho foram consideradas duas temáticas de grande relevância no autor mencionado: a antropologia e a história. A primeira parte se encarrega em apresentar os fundamentos antropológicos da dimensão religiosa. Para isso foi importante compreender o conceito de pessoa, de sujeito e de liberdade em nosso autor. Em Pannenberg, o tema da abertura caracteriza uma antropologia que não se fecha diante do puro imanente, mas se coloca frente ao infinito mistério de Deus. O ser humano é aquele que transcende a sua finitude e se abre ao infinito. A noção de imagem e semelhança de Deus oferece bases para uma leitura teológica da antropologia. A segunda parte trabalha o tema da revelação como história no contexto judaicocristão. Conforme o teólogo alemão a revelação se dá de forma indireta através dos acontecimentos históricos. Nesse sentido a primeira parte se harmoniza com a segunda, pois somente se pode falar de história se consideramos o ser humano como seu protagonista. É na história humana que Deus se revela como criador, libertador e salvador da humanidade. O ápice da revelação se dá em Jesus Cristo, pois nele ela chega ao seu ponto final. Jesus já e de forma proléptica o que acontecerá com todo ser humano. A sua ressurreição antecipa a esperança futura reservada a cada pessoa. Em conformidade com o que foi afirmado, a escatologia se faz muito importante para o teólogo luterano. É nela que acontecerá o desfecho final da história humana, chamado por ele de fim da história. Jesus Cristo é o centro unificador desse futuro, em que haverá uma perfeita harmonia entre passado, presente e futuro no presente eterno de Deus. A realização final da pessoa será a eterna participação do amor divino, da trindade. Amor já manifestado pelo Pai desde o início da criação.

Palavras-chave: Revelação, antropologia, história, Deus, Wolfhart Pannenberg. 